\title{
Thermotelemetric study on the hibernation of a common hamster, Cricetus cricetus (Linnaeus, 1758), under natural circumstances
}

\author{
R.E.M.B. Gubbels ${ }^{1}$, J.J. van Gelder ${ }^{1} \&$ A. Lenders ${ }^{2}$

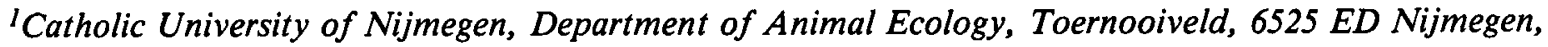 \\ The Netherlands; ${ }^{2}$ Groenstraat 106, 6074 EL Melich, The Netherlands
}

Keywords: Hibernation, Cricetus cricetus, thermotelemetry

\begin{abstract}
By means of radio-thermotelemetry a study was made of the thermoregulatory patterns during hibernation of a common hamster, Cricetus cricetus (L., 1758) under natural conditions.

In the euthermic state, body temperature $\left(T_{b}\right)$ fluctuated between 36.4 and $38.6^{\circ} \mathrm{C}$ with $\mathrm{T}_{b}$ higher than $37.0^{\circ} \mathrm{C}$ probably indicating activity. The hamster went into deep hibernation 23 times. The entrance into hibernation lasted $20-60$ hours, the state of deep hibernation 17-110 hours and the subsequent arousal 3.5-6.5 hours. Both the duration of arousal and of a bout of hibernation seemed to be negatively correlated with $T_{b}$. The euthermic interbout state lasted 4-25 hours. The minimum $T_{b}$ during deep hibernation ranged between 10.0 and $2.6^{\circ} \mathrm{C}$. Sixteen bouts of hibernation could be observed completely with their respective intervals from entrance to arousal. In 11 bouts arousal followed after a drop of the ambient temperature $\left(T_{a}\right)$, in four bouts after a rise of $T_{a}$ and in one bout at a constant $T_{a}$.
\end{abstract}

\section{Résumé}

Une étude des phénomènes de thermorégulation pendant l'hibernation d'un hamster commun, Cricetus cricetus (L., 1758) dans des conditions naturelles, a été effectuée au moyen de la radio-thermotélémetrie.

A l'état euthermique, la température du corps $\left(T_{b}\right)$ a varié de 36,4 à $38,6^{\circ} \mathrm{C}$, une $T_{b}$ supérieure à $37^{\circ} \mathrm{C}$ indiquant probablement l'existence d'activité. Le hamster est tombé en hibernation profonde 23 fois. L'entrée en hibernation dure 20-60 heures, l'état d'hibernation profonde $17-110$ heures, le reveil subséquent 3,5-6,5 heures. Durée du reveil et durée d'une période d'hibernation semblent être négativement correlées à la $T_{b}$. La phase euthermique entre deux périodes d'hibernation dure 4-25 heures. $\mathrm{La} \mathrm{T}_{b}$ minimum pendant l'hibernation profonde, varie de 10 à $2,6^{\circ} \mathrm{C}$. Seize périodes d'hibernation ont pu être observées, avec les intervales respectifs, depuis l'entrée en hibernation jusqu'au reveil. Dans le cas de 11 périodes d'hibernation, le reveil a fait suite à une baisse de la température ambiante $\left(T_{a}\right)$, dans le cas de quatre périodes il s'est produit après une hausse de la $T_{a}$, et dans un seul cas il s'est produit à une $T_{a}$ démeurée constante.

\section{Introduction}

Since the experiments of Horvath (1881) the knowledge of rodent hibernation has considerably increased. Especially during the last decade intensive research has led to a better understanding of the neuro-endocrine regulation of this process.

Studies on rodent hibernation have been performed on a limited number of species, in particular the golden hamster (Mesocricetus auratus Waterhouse), a variety of dormice (Gliridae) and ground squirrels (Citellus spec.). As interspecific differences exist (Lyman \& O'Brien, 1974; Pivorun, 1976; Twente et al., 1977; Lyman et al., 1982) a general view on the physiology and regulation of rodent hibernation is impossible. Almost all investigations, mentioned in the literature, are carried out under controlled laboratory conditions.

This investigation was undertaken in order to characterize the hibernation of the species Cricetus cricetus (Linnaeus, 1758), the common hamster, under natural conditions. Emphasis was laid on quantifying various thermoregulatory patterns. Data on this subject are very scanty and almost confined to the arousal process (Eisentraut, 1928; Raths \& Külzer, 1976). Quantitative data concern- 
ing the course of body temperature $\left(\mathrm{T}_{\mathrm{b}}\right)$ during the entrance into hibernation or during the deep hibernation state (abdominal $\mathrm{T}_{\mathrm{b}}$ below $10.0^{\circ} \mathrm{C}$ ) are practically unavailable.

By means of radiotelemetry coupled to intracorporal temperature measurement the course of $T_{b}$ during hibernation could be followed in the natural habitat of the animal. By applying this technique disturbance of the hamster in the field is sharply reduced and prolonged studies can be conducted.

\section{Materials and methods}

The experimental animal was caught on 14 October 1984 in the municipality of Stein, in the south of the Dutch province of Limburg, in a small-scale agricultural area. The burrow was situated in a ryefield. The animal was a subadult male weighing $276 \mathrm{~g}$.

In the Biomedical Centre of the State University of Limburg, a temperature sensitive transmitter (weight $3.9 \mathrm{~g}: 1.4 \%$ of body mass) was surgically implanted in the abdominal cavity, following the procedure of Lenders et al. (1986). By means of the transmitter $T_{b}$ could be measured accurately to $0.1^{\circ} \mathrm{C}$. For technical details on the modified transmitter type used see Olders et al. (1986).

After a post-operation observation period of 10 days the animal was returned to its burrow. During the period of 26 October to 7 April $T_{b}$ was followed radiotelemetrically. Due to the fact that the transmitter had a small range (about $60 \mathrm{~m}$, hamster above ground), the hamster was not tracked at night during the pre-hibernation phase. In this way disturbance of the natural behavior was prevented.

Measurements of $T_{b}$ carried out during the prehibernation phase and the euthermic period between two bouts of hibernation were done at 15 minute intervals. Entrance into hibernation was followed by measuring $T_{b}$ at $15,30,60,120$ or 240 minute intervals (depending on the rate $T_{b}$ dropped). During the beginning of the deep hibernation state measurements were done every eight hours. This frequency was increased as the expected end of this state approached. Nevertheless the be- ginning of arousal was missed in some cases. Observations during this process were made every minute.

The ground temperature at nest depth was taken as an approximation of the ambient temperature $\left(T_{a}\right)$ of the hamster. $T_{a}$ was measured with temperature probes at eight different depths between 5 and $65 \mathrm{~cm}$ at a distance of approximately $4 \mathrm{~m}$ from the nest. During the entire hibernation period ground temperatures were determined each day at $07.00 \mathrm{~h}$ and $14.00 \mathrm{~h}$. The temperature could be measured with an accuracy of $0.1^{\circ} \mathrm{C}$. After the final bout of hibernation the burrow was opened in order to determine the exact nest depth.

\section{Results}

In the pre-hibernation phase $T_{b}$ fluctuated between 36.4 and $38.6^{\circ} \mathrm{C}$. During the daytime this value varied between 36.4 and $37.0^{\circ} \mathrm{C}$. At leaving the burrow and returning to it $T_{b}$ was between 37.0 and $38.6^{\circ} \mathrm{C}$. Such a relatively high $T_{b}$ also appeared once or twice at night in the burrow, lasting $0.8-1.2$ hours. Such periods were followed by periods in which $T_{b}$ fluctuated between 36.4 and $37.0^{\circ} \mathrm{C}$. These lasted $0.75-5$ hours.

Between 16 November 1984 and 3 April 1985 the hamster went into deep hibernation 23 times. During this period the burrow was not left. The course of $T_{b}$ was nearly the same for every bout of hibernation (Fig. 1). At a certain point of time $T_{b}$ gradually fell down to a minimum level $\left(\mathrm{T}_{\min }\right)$. Within the 23 bouts $T_{\min }$ ranged from 2.6 to $10.0^{\circ} \mathrm{C}$. Subsequent to reaching $\mathrm{T}_{\text {min. }}$ there was a period of deep hibernation lasting between 17 and 110 hours. Arousal took a relatively short time: 3.5-6.5 hours. Seven arousals could be followed from the start. For $T_{\min }$ between 9.0 and $6.4^{\circ} \mathrm{C}$ arousal lasted 3.5-4.5 hours, for $T_{\min }$ between 3.6 and $2.9^{\circ} \mathrm{C}$ the duration was $6.0-6.5$ hours. In Fig. 2 this relation is shown. In the same figure it can also be noted that at a certain temperature, varying between 10 and $13^{\circ} \mathrm{C}$, the rising rate of $T_{b}$ increased. The total duration of a bout ranged between 40.5 and $\mathbf{1 7 6 . 5}$ hours. The euthermic state between two bouts lasted 4-25 hours. In this period 


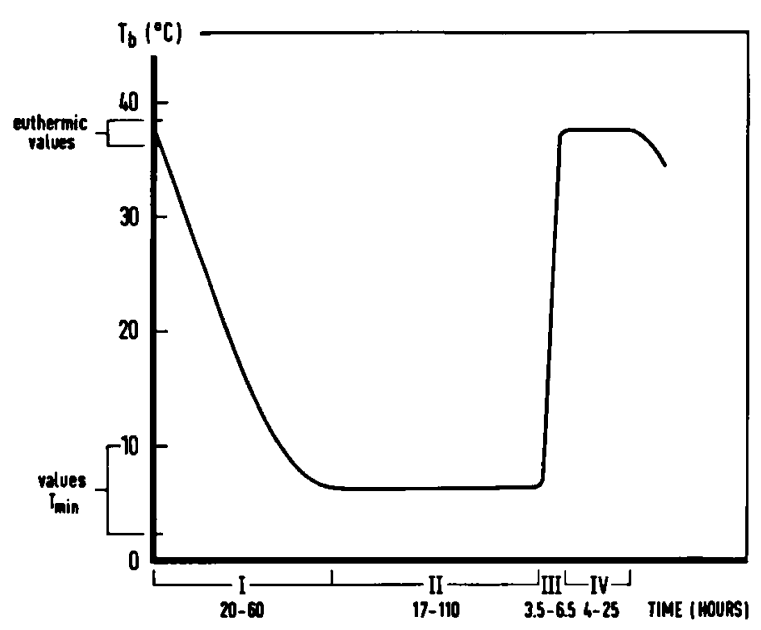

Fig. 1. General course of $\mathrm{T}_{\mathrm{b}}$ during hibernation. The range of values for $T_{\min }$ and $T_{b \text {,euthermic }}$ is given as well as the range of duration of each part of the hibernation process (I-IV) $(n=23$ bouts, 22 euthermic interbout periods). I = Entrance into hibernation; II = Deep hibernation state; III = Arousal from hibernation (see also Fig. 2); IV = Euthermic period between 2 bouts.

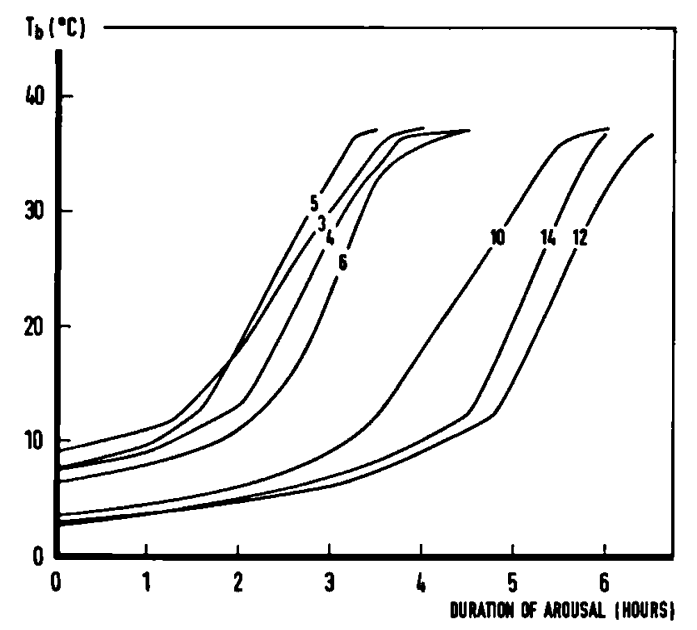

Fig. 2. The course of abdominal $T_{b}$ during the seven arousals from deep hibernation that could be followed entirely (bouts $3-6,10,12,14)$.

$T_{b}$ fluctuated between the same values as in the pre-hibernation phase. At the start and the end of the hibernation period the bouts lasted shorter than in the middle (Fig. 3). In the same figure the $T_{\min }$. of every bout (except bout 7, 8 and 9) is given.

The ground temperature at a depth of $55 \mathrm{~cm}$, the depth of the nest, was assumed to be the best measure for the temperature directly surrounding the

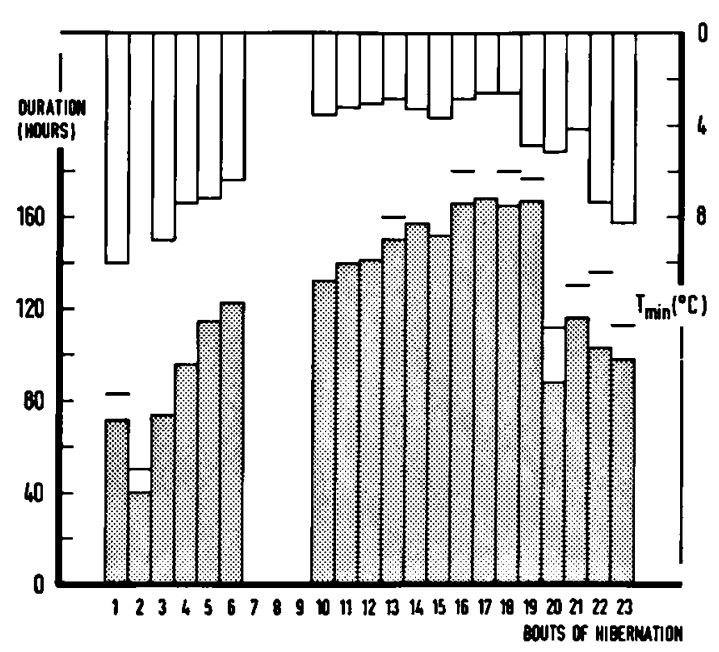

Fig. 3. Duration of 23 bouts of hibernation in relation to the $T_{\min .}$ of every bout. The duration of the bouts 7,8 , and 9 could not be determined; the duration of the bouts $1,2,13,16$ and 18-23 could not exactly be established. Here, the possible value ranges between a minimum and maximum limit, shown by means of a dash.

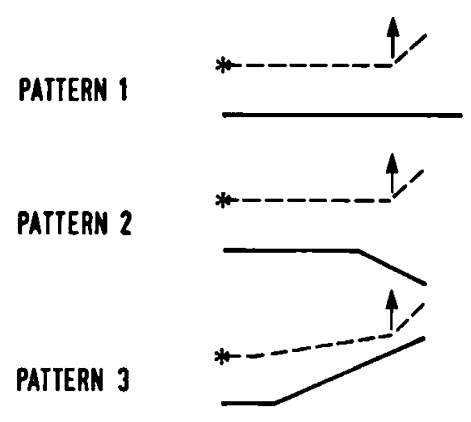

Fig. 4. Three observed patterns in the relation between $T_{b}$ (dotted line) and $T_{a}$ (straight line). ${ }^{*}$ indicates the moment $T_{\text {min. }}$ is reached, $I$ the moment of arousal.

hamster $\left(\mathrm{T}_{\mathrm{a}}\right)$. During the hibernation period $\mathrm{T}_{\mathrm{a}}$ dropped gradually from about 10.0 to $1.2^{\circ} \mathrm{C}$ (around bout 18) and rose after this to $7.5^{\circ} \mathrm{C}$ at the end of bout 23. $T_{a}$ fluctuated almost daily $\left(0.0-1.8^{\circ} \mathrm{C}\right)$ and was never constant for longer than five days.

The relation between $T_{b}$ and $T_{a}$ is shown in Fig. 4. $T_{b}$ is given from the moment that $T_{\min }$. was reached (indicated by ${ }^{*}$ ). At this moment $T_{\text {min. }}$ was minimally 0.0 and maximally $1.8^{\circ} \mathrm{C}$ higher than $\mathrm{T}_{\mathrm{a}}$ with a lowest $T_{\min .}$ of $2.6^{\circ} \mathrm{C}$. In 16 bouts the relation $T_{b}-T_{a}$ could exactly be determined. In this re- 
lation three patterns could be distinguished. After $T_{\text {min. }}$ is reached $T_{b}$ remains constant with a constant $T_{a}$ (Fig. 4, pattern 1), in one bout followed by arousal. With a falling $T_{a}, T_{b}$ also remains constant, in 11 of the 16 bouts followed by arousal (Fig. 4, pattern 2). A greater or smaller rise in $T_{b}$ was noticed when $T_{a}$ increased. In four bouts this resulted in arousal (Fig. 4, pattern 3). Three times within a bout a drop in $T_{b}$ was observed (data not shown) after a falling of $T_{a}$. This is in contradistinction to pattern 2 shown in Fig. 4.

\section{Discussion}

The $T_{b}$-values measured in the pre-hibernation phase are normal for the common hamster. They vary between the minimum $\left(35.0^{\circ} \mathrm{C}\right)$ and maximum $\left(39.5^{\circ} \mathrm{C}\right.$ ) values (average around $37-38^{\circ} \mathrm{C}$ ) mentioned in literature (Raths, 1963; Malan \& Hildwein, 1969; Weiner \& Gorecki, 1975; Gorecki, 1977). According to Gorecki (1977) and Visinescu (1968) there is a circadian rhythm in the daily $T_{b^{-}}$ fluctuations. The highest values are reached respectively in the afternoon and at night. In this study such a rhythm was not established. The relatively high $T_{b}$ measured in the pre-hibernation phase and the euthermic state between two bouts probably indicate activity of the hamster. $A$ difference in $T_{b}$ between the active $\left(37.0-38.6^{\circ} \mathrm{C}\right)$ and the resting/sleeping state $\left(36.4-37.0^{\circ} \mathrm{C}\right)$ was also found by Twente \& Twente (1965) in the golden-mantled ground squirrel, Citellus lateralis.

The duration of arousal proved to be dependent on $T_{\text {min. }}$ : a lower $T_{\text {min. }}$ lengthened this process. Such a correlation could not be established for the entrance into hibernation. The shorter duration of arousal observed by Eisentraut (1928) and Raths (1976), 2.0-4.0 hours, could perhaps be due on one hand to different experimental conditions (e.g., laboratory experiments, higher $T_{\min }$ ) and on the other hand to different means of determining $T_{b}$. Raths $(1957,1961,1963)$, for example, measured the cheekpouch temperature as opposed to the abdominal temperature measured in this study. During arousal the cheekpouch temperature rises more quickly than the abdominal temperature (Lyman,
1948; Lyman \& Chatfield, 1950). The course of the rise in $T_{b}$ during arousal (Fig. 2) is typical for many rodent species. Eisentraut (1928) and Raths (1957) already observed this when studying Cricetus cricetus. It is generally accepted that the sudden rise in abdominal bodywarming at a particular $T_{b}$ is due to the cessation of a vasoconstriction in the anterior part of the body (Lyman et al., 1982).

Pengelley \& Fisher (1961), Twente et al. (1977) and Pivorun (1976) mention the presence of a negative correlation between $T_{a}$ and the duration of a bout of hibernation. As $T_{b}$ is approximately the same as $T_{a}$ this negative correlation should also be valid for $T_{b}$. This investigation seems to indicate there is indeed such a correlation (Fig. 3).

It is very difficult to measure a relevant $T_{a}$ of the hamster during hibernation. The measurements may not disturb the animal. Further, the $T_{a}$ measured must not be influenced by the hamster itself and at the same time it has to give a good indication of the energy flow between the hamster and its environment. Our $\mathrm{T}_{\mathrm{a}}$-determination at a distance of 4 $m$ from nest site and at nest depth comes up to these requirements the best.

This study shows that when in a certain bout $T_{\text {min. }}$ is reached and $T_{a}$ drops (Fig. 4, pattern 2), $T_{b}$ remains constant and is often followed by arousal. These results are compatible with those found in particular by Heller and co-workers in their studies of the golden-mantled ground squirrel. Citellus lateralis (Heller \& Hammel, 1972; Heller \& Colliver, 1974; Heller, 1979). Particular brain-areas appear to be involved in the control of hibernation. The pre-optic anterior hypothalamic area plays a major role in the regulation of $T_{b}$. In this brainarea the set-point $\left(\mathrm{T}_{\text {set }}\right)$ threshold for temperature regulation is situated. Usually $T_{b}$ is slightly above $T_{\text {set }}$. A decrease in $T_{b}\left(=T_{\text {min. }}\right.$ during deep hibernation) due to a decrease in $T_{a}$ can result in the thermosensitive hypothalamus reaching a temperature which is lower than $T_{\text {set }}$. This results in heat producing processes that restore $T_{b}$ to a value above $T_{\text {set }}$. The stimulated heat production not only keeps $T_{b}$ constant with decreasing $T_{a}$ but also often results in arousal. In three cases a drop in $T_{a}$ was followed by a drop in $T_{b}$ (in contrast to what has been said before). This fall in $T_{b}$ followed after 
a number of $T_{a}$-rises in which $T_{b}$ also rose. The fall in body temperature is probably the result of the fact that $T_{b}$ was well above $T_{\text {set }}$. Body temperature returned to the previous value of $T_{\min }$. The joint rise of $T_{b}$ and $T_{a}$ (Fig. 4, pattern 3 ) is probably the result of a relatively slow release of warmth.

The results of this study are based on the data of one subadult male. They show clear trends in certain thermoregulatory patterns (Figs 2-4). Although intra-specific differences might occur, probably these trends are also present in adult males and (sub)adult females. It would be very interesting to study this, however such an investigation is very time-consuming. The method employed in this study has proved to be ideal for prolonged research under natural conditions but at the same time it is very labor-intensive. Automatization of the observations in the field would be a suitable solution. We are at work on the realization of such a system.

\section{Literature}

Eisentraut, M. 1928. Über die Baue und den Winterschlaf des Hamsters. Z. Säugetierk. 3: 172-208.

Gorecki, A. 1977. Energy flow through the common hamster population. Acta Theriol. 22: 25-66.

Heller, H.C. 1979. Hibernation: Neural aspects. Ann. Rev. Physiol. 41: 305-321.

Heller, H.C. \& G.W. Colliver, 1974. CNS regulation of bodytemperature during hibernation. Am. J. Physiol. 227: 583-589.

Heller, H.C. \& H.T. Hammel, 1972. CNS control of bodytemperature during hibernation. Comp. Biochem. Physiol. 41A: 349-359.

Horvath, A. 1881. Einfluss verschiedener Temperaturen auf die Winterschläfer. Verh. Phys. Med. Ges. Würzberg 15: 187-219.

Lenders, A., R.E.M.B. Gubbels \& J.J. Van Gelder, 1986. Temperatuurgevoelige radiotelemetrie als onderzoekmethode bij de hamster Cricetus cricetus (L., 1758). Lutra 29: 261-267.

Lyman, C.P. 1948. The $\mathrm{O}_{2}$-consumption and temperature regu- lation of hibernating hamsters. J. Exper. Zool. 109: 55-78. Lyman, C.P. \& P.O. Chatfield, 1950. Mechanisms of arousal in hibernating hamsters. J. Exper. Zool. 114: 491-516.

Lyman, C.P. \& R.C. O'Brien, 1974. A comparison of temperature regulation in hibernating rodents. Am. J. Physiol. 227: 218-223.

Lyman, C.P., J.S. Willis, A. Malan \& L.C.H. Wang, 1982. Physiological ecology: hibernation and torpor in mammals and birds. Academic Press, New York.

Malan, A.\& G. Hildwein, 1969. Thermorégulation en ambiance chaude d'un hibernant le hamster d'Europe (Cricetus cricetus) comparaison avec le rat blanc. Arch. Sci. Physiol. 15: $377-420$.

Olders, J.H.J., J.J. Van Gelder \& J. Krammer, 1986. A thermosensitive transmitter for radio tracking small animals. Neth. J. Zool. 35: 479-485.

Pengelley, E.T. \& K.C. Fisher, 1961. Rhythmical arousal from hibernation in the golden-mantled ground squirrel, Citellus lateralis tescorum. Can. J. Zool. 39: 105-120.

Pivorun, E.B. 1976. A biotelemetry study of the thermoregulatory patterns of Tamias striatus and Eutamias minimus during hibernation. Comp. Biochem. Physiol. 53A: 265-271.

Raths, P. 1957. Die bioelektrische Hirntätigkeit des Hamsters im Verlaufe des Erwachens aus Winterschlaf und Kältenarkose. Z. Biol. 110: 62-80.

Raths, P. 1961. Über das Verhalten des Blutzuckers im Winterschlaf und Hypothermie. Z. Biol. 112: 282-289.

Raths, P. 1963. Über das Serum-Natrium, -Kalium und -Kalzium des Winterschlafenden und hypothermischen Hamsters (Cricetus cricetus). Z. Biol. 113: 173-204.

Raths, P. \& E. Kulzer, 1976. Physiology of hibernation and related lethargic states in mammals and birds. Bonn. Zool. Monogr. 9: 1-93.

Twente, J.W. \& J.A. Twente, 1965. Regulation of hibernating periods by temperature. Proc. natn. Acad. Sci. 54: 1058-1061.

Twente, J.W., J.A. Twente \& R.M. Moy, 1977. Regulation of arousal from hibernation by temperature in three species of Citellus. J. appl. Physiol. 42: 191-195.

Visinescu, N. 1968. The homeostasis and rhythms of the energetic metabolism, bodytemperature and motor activity in hamster (Cricetus cricetus). Rev. roum. Biol. (Zool.) 13: $139-144$.

Weiner, J. \& A. Gorecki, 1975. Radiotelemetry used in deep body temperature measurements of animals. Wiadomosci Ekologiczne 21: 233-241.

Received: 27 June 1988 